Moderasi Jurnal Studi Ilmu Pengetahuan Sosial, Volume 2, No. 2, h. 29-4I

\title{
MENANAMKAN NILAI-NILAI KEHIDUPAN BAGI ANAK DALAM LINGKUNGAN KELUARGA DIMASA PANDEMI COVID 19
}

\author{
Riska Elfira \\ Dosen Fakultas Tarbiyah dan Ilmu Keguruan IAIN Palu \\ riska_elfira@iainpalu.ac.id
}

\begin{abstract}
During the COVID-19 pandemic, all social activities are restricted. Of all the obstacles complained about, there is a positive side that we can take from the restrictions on social activities recommended by the government. One of them is spending time with family. This will restore the role of the family as the first and foremost institution in the educational environment. Families are not just giving birth to children, but how families can instill life values for children in their environment. The government's policy on Work From Home (WFH), needs to be welcomed by families, with WFH policy families have many opportunities to accompany children directly when studying so they can find out the extent of children's developmental abilities in learning and become an opportunity for families to learn. forge a stronger emotional closeness between parents and children. There are four parenting styles that families need to know, namely authoritarian parenting, authoritative parenting, neglecting parenting, and submissive parenting. The most effective parenting style to apply is the authoritative parenting style in which families encourage children to be independent but still set limits on what children can do and what children cannot do. Children will recognize the values of life from the teaching obtained in the family environment. The values of life that need to be instilled in children are social values, citizenship values, work values, religious values, and general values. The optimal implementation of the role of the family can provide opportunities for families to give birth to quality future generations so that they are expected to become quality leaders of the nation.
\end{abstract}

Keywords: Family, Life Values

Abstrak

Pada masa pandemi Covid 19, segala aktifitas sosial dibatasi. Dari segala kendala yang dikeluhkan ada sisi positif yang bisa kita ambil dari pembatasan aktifitas sosial yang di anjurkan oleh pemerintah. Salah satunya adalah banyaknya waktu berkumpul bersama keluarga. Hal ini akan mengembalikan peran keluarga sebagai institusi pertama dan utama dalam lingkungan pendidikan. Keluarga bukan hanya sekedar melahirkan anak, tapi bagaiamana keluarga dapat menanamkan nilai-nilai kehidupan bagi anak dalam lingkungannya. Kebijakan Pemerintah akan Work From Home (WFH), hal ini perlu disambut baik oleh keluarga, dengan adanya kebijakan WFH keluarga memiliki banyak kesempatan untuk mendampingi anak secara langsung ketika belajar sehingga dapat mengetahui sejauh mana tingkat kemampuan perkembangan anak dalam belajar dan menjadi kesempatan bagi keluarga untuk menjalin kedekatan emosional yang lebih kuat antara orang tua dan anak. Ada empat gaya pengasuhan yang perlu diketahui oleh keluarga yaitu pengasuhan otoritarian, pengasuhan otoritatif, pengasuhan yang mengabaikan dan pengasuhan yang menuruti. Gaya pengasuhan yang paling efektif untuk diterapkan adalah gaya pengasuhan otoritatif yang mana keluarga mendorong anak untuk mandiri namun tetap memberi batasan akan akan hal - hal yang bisa dilakukan oleh anak dan yang tidak boleh dilakukan oleh anak. Anak akan mengenal nilai- nilai kehidupan dari pengajaran yang diperoleh dalam lingkungan keluarga. Adapun nilai-nilai kehidupan 
yang perlu di tanamkan dalam diri anak yaitu nilai-nilai sosial, nilai kewarganegaraan, nilai kerja, nilai agama, dan nilai-nilai umum. Pelaksanaan peran keluarga yang optimal dapat memberikan peluang kepada keluarga untuk melahirkan generasi penerus berkualitas sehingga diharapkan akan menjadi pemimpin bangsa yang berkualitas.

Kata Kunci : Keluarga, Nilai-nilai Kehidupan

\section{Pendahuluan}

Keluarga merupakan sumber kepribadian anak. Hal inilah menjadikan pendidikan dalam lingkungan keluarga menjadi sangat penting untuk mendapat perhatian dari anggota keluarga lainnya atau yang lebih dewasa. Lingkungan keluarga sebagai system sosial terkecil, sangat efektif menjadi peletak nilai-nilai dasar kehidupan. Meniru merupakan salah satu faktor perkembangan yang dilalui oleh anak. Orang tua akan menjadi model pertama bagi tumbuh kembang anak dalam lingkungan keluarga. Segala pendidikan yang diperoleh oleh anak dalam lingkungan keluarganya akan tertanam dalam diri anak dan akan menjadi sikap atau karakter utama anak. Orang tua mempunyai peran yang tidak bisa digantikan oleh siapapun dan apapun. Dalam kehidupannya, orang tua diharapkan mampu memenuhi kebutuhan anak, seperti kebutuhan dasar yaitu berupa kebutuhan sandang, pangan, papan dan kebutuhan akan pendidikan.

Pada masa pandemi Covid 19, segala aktifitas sosial dibatasi, termasuk kegiatan pembelajaran yang harus dilakukan di rumah. Banyak dampak negatif yang dirasakan baik dari pihak siswa, orang tua ataupun dari pihak guru. Mulai dari kendala fasilitas yang digunakan siswa untuk pembelajaran, seperti tidak adanya handphone, kendala jaringan sampai kepada keterbatasan ekonomi untuk pembelian kuota internet. Adapula kendala bagi orang tua yaitu orang tua kurang paham terhadap pendekatan baru dalam pembelajaran berbasis online, kurang memahami materi pembelajaran anak sehingga peran orang tua sebagai pendamping belajar tidak berjalan dengan baik. Selain itu dari pihak guru mengalami kendala dengan masih adanya guru yang belum mengerti membuat materi ajar berbasis online, belum bisa menggunakan aplikasi-aplikasi pembelajaran dan juga kendala jaringan dan kuota internet. Hal ini tentunya menjadikan kegiatan pembelajaran tidak berjalan dengan efektif.

Dari segala kendala yang dikeluhkan ada sisi positif yang bisa kita ambil dari pembatasan aktifitas sosial yang di anjurkan oleh pemerintah. Salah satunya adalah banyaknya waktu berkumpul bersama keluarga. Dalam kesempatan ini keluarga dapat memainkan perannya sebagai manager bagi kehidupan anak. Keluarga dapat mengikuti tahap perkembangan anak, melakukan komunikasi secara intens, memotivasi, dan melakukan kegiatan-kegiatan di rumah secara bersamaan. Hal ini tentunya akan mampu menjalin kembali rasa kehangatan dalam lingkungan keluarga.

Dengan banyaknya waktu berkumpul bersama keluarga, akan mengembalikan peran keluarga sebagai institusi pertama dan utama dalam lingkungan pendidikan. Keluarga akan mempunyai banyak waktu dalam menentukan atau memperbaiki pola pengasuhan terhadap anak. Setiap keluarga hendaknya memiliki strategi dalam 
menjalankan perannya sebagai institusi pertama bagi anak. Bukan hanya sekedar melahirkan anak, tapi bagaiamana keluarga dapat menanamkan nilai-nilai kehidupan bagi anak dalam lingkungan keluarga.

\section{Pembahasan}

\section{Masa Pandemi Covid 19}

Covid-19 pertama dilaporkan di Indonesia pada tanggal 2 Maret 2020 sejumlah dua kasus. ${ }^{1}$ Pada 12 Maret 2020, WHO mengumumkan Covid-19 sebagai pandemik. ${ }^{2}$ Begitu cepat tingkat penyebaran virus Covid 19. Hal ini menjadikan pemerintah harus sigap dalam melakukan penangaan pencengahan hingga menyiapkan fasilitas kesehatan untuk memberikan pelayanan terbaik pada pasien Covid 19. Berbagai upaya dilakukan oleh pemerintah untuk menekan penyebaran virus Covid 19 di Indonesia. seperti anjuran menggunakan masker, melakukan Physical distancing, sosial distancing, pembatasan sosial berskala besar (PSBB), hingga kepada pemberlakuan pembatasan kegiatan masyarakat (PPKM) yang disesuaikan menurut level assesmen masing-masing kabupaten dan kota . Penentuan level yang didasarkan pada standar WHO yaitu level Assesmen situasi pandemic yang mengukur antara laju transmisi virus dibandingkan dengan kapasitas respon 3T. Selain itu juga menggunakan indikator kasus konfirmasi harian, tingkat BOR, dan pencapaian vaksinasi. ${ }^{3}$

Saat ini upaya terbaik dalam menghindari penularan virus Covid 19 adalah disiplin mematuhi protokol kesehatan dan melakukan vaksinasi. Ada beberapa jenis vaksin yang digunakan di Indonesia yakni Sinovac, astra Zeneca, Sinopharm, Moderna, Pfizer, dan Novavax. ${ }^{4}$ Pelayanan vaksinasi Covid- 19 dapat dilaksanakan di fasilitas pelayanan kesehatan masyarakat milik pemerintah pusat, pemerintah daerah provinsi, pemerintah daerah kabupaten/kota, atau milik swasta yang memenuhi persyaratan. Hingga saat ini data vaksinasi Indonesia terupdate 26 Desember 2021 yaitu sebanyak 156.641.778 jiwa masyarakat Indonesia yang telah melakukan vaksinasi ke I, 110.620.807 jiwa yang telah melakukan vaksinasi ke II, dan sebanyak 1.280.673 yang telah selesai melakukan vaksinasi tahap III. ${ }^{5}$ Masih ada sekitar 208.265.720 jiwa yang menjadi target sasaran vaksin Nasional. ${ }^{6}$

Salah satu kebijakan yang dibuat oleh pemerintah guna untuk meminimalisir penyebaran virus Covid-19 yaitu Work From Home (WFH). Kebijakan ini menjadikan

\footnotetext{
${ }^{1}$ World Health Organization. Situation Report - 42 [Internet]. 2020 [updated 2020 March 02; cited 2020 March 15]. Available from: https://www.who.int/docs/default-source/ coronaviruse/situation-reports/20200302-sitrep-42-covid-19. pdf?sfvrsn=224c1add_2.

2 World Health Organization. WHO Director-General's opening remarks at the media briefing on COVID-19 - 11 March 2020 [Internet]. 2020 [updated 2020 March 11]. Available from: https://www.who.int/dg/speeches/detail/who-director-generals-opening-remarks-at-the-mediabriefing-on-covid-19---11- march-2020.

3Ekon.gi.id. https://ekon.go.id/publikasi/detail/3159/penerapan-ppkm-untukmengendalikan-laju-covid-19- dan-menjaga-kehidupan-masyarakat. Di akses 20 Desember 2021

4 Tentang vaksin. https://covid19.go.id/tentang-vaksin-covid19. Di akses 20 Desember 2021

5 https://covid19.go.id/p/berita/data-vaksinasi-covid-19-update-26-desember-2021. Di akses 26 Desember 2021

6 Ibid,
} 
segala aktivitas dilakukan dari Rumah, mulai dari kegiatan perkantoran hingga kegiatan pembelajaran. Kementrian Pendidikan Indonesia mengeluarkan kebijakan mengganti kegiatan pembelajaran tatap muka dengan pembelajaran dilakukan secara daring. Berubahnya kegiatan pembelajaran ini menuntut Siswa dan Guru harus menguasai teknologi. Kegiatan pembelajaran yang dilakukan dari rumah menjadi tugas tambahan bagi keluarga. Dimana keluarga harus terlibat secara langsung dalam mendampingi kegiatan belajar anak dan juga mempunyai kewajiban melaporkan hasil belajar Anak kepada Guru. Hal ini sebenarnya perlu disambut baik oleh keluarga, dengan adanya kebijakan WFH keluarga memiliki banyak kesempatan untuk mendampingi anak secara langsung ketika belajar sehingga dapat mengetahui sejauh mana tingkat kemampuan perkembangan anak dalam belajar dan menjadi kesempatan bagi keluarga untuk menjalin kedekatan emosional yang lebih kuat antara orang tua dan anak. Sehingga akan lebih mudah bagi keluarga menjalankan perannya dalam menanamkan nilai-nilai kehidupan bagi Anak.

\section{Peran Keluarga dalam Pendidikan Anak}

Dalam kehidupan pertamanya anak akan tumbuh dan berkembang dalam lingkungan Keluarga. Lingkungan dimana anak akan mendapatkan pengajaran pertama dalam hidupnya. Sejak lahir anak akan di asuh sepenuhnya oleh ibunya. Ibu menjadi orang pertama dalam menanamkan nilai-nilai kehidupan bagi seorang anak. Ibu yang memberi nilai tinggi pada kemampuan berteman, berbagi dengan orang lain, dan memimpin atau memengaruhi anak lain memiliki anak yang lebih asertif, prososial, dan mampu memecahkan masalah dari pada ibu yang kurang menghargai kemampuan-kemampuan tadi. ${ }^{7}$ Seiring dengan perkembangannya anak akan tumbuh dan mulai mengenal lingkungan selain ibunya, anak akan mulai mengenal ayahnya, kakaknya, neneknya dan orang lain disekitarnya. Dalam lingkungan keluarga inilah orang tua akan memberikan pendidikan pertama bagi anaknya. Singgih D. Gunarsa mengungkapkan, bahwa peran keluarga sangat besar dalam menciptakan kesejahteraan umum melalui bimbingan dan pendidikan anaknya secara bertanggung jawab. Peran keluarga sangat penting, yang mana perlu disadari oleh keluarga bahwa anak harus yakin akan adanya pegangan dan gambaran kesatuan antara ayah dan ibu, gambaran kesatuan antara keduanya akan memberikan perasaan aman dan terlindungi bagi anak. Anak dalam perkembangan menuju ke manusia dewasa yang harmonis memerlukan suasana aman. ${ }^{8}$

Dimasa pertumbuhannya anak belum bisa menentukan apa yang bisa ia lakukan dan belum bisa untuk dilakukan, dan bagaimana cara melakukannya dan bagaimana cara menghindarinya. Sebagaimana dalam teori tabula rasa yang dicetuskan oleh ahli filosofi Inggris Jhon Locke. Ia membantah bahwa anak-anak tidak buruk sejak lahir, Melainkan seperti papan kosong. Locke percaya bahwa pengalaman masa kanak-kanak sangat menentukan karakteristik seseorang saat

\footnotetext{
${ }^{7}$ Jhon W Sanstrock, Perkembangan Anak, Edisi Kesebelas. Jilid 2( Jakarta:Erlangga, 2007), 158

${ }^{8}$ Singgih D. Gunarsa, Psikologi Untuk Keluarga (Jakarta: PT. BPK Gunung Mulia, 2011), 14 .
} 
dewasa. Ia menyarankan para orang tua menghabiskan waktu bersama anak-anak mereka dan membantu mereka menjadi masyarakaat yang berguna. ${ }^{9}$ Dalam kesempatan ini keluarga memiliki peran yang sangat besar yaitu sebagai manajer kehidupan anak. Pada masa bayi hal ini mungkin meliputi membawa anak kedokter dan mengatur pengasuhan anak. Pada masa kanak-kanak, peran manajerial berupa menentukan preschool mana yang harus dimasuki anak, mengarahkan anak agar memakai pakaian yang bersih dan menjauhkan mainan dan menyusun aktifitas anak setelah sekolah. Pada masa dewasa, peran manajerial mencakup menetapkan jam dan memantau kuliah dan minat karir anak..$^{10}$

Memegang peran sebagai manajer anak, keluarga dapat mengatur hubungan sosial anak dengan teman sebaya, dengan yang lebih muda atau dengan yang lebih tua. Ini dilakukan untuk mengajarkan anak tentang etika- etika dalam hubungan sosial. Dalam sebuah studi anak dari orang tua yang mengatur kontak dengan teman sebaya memiliki jumlah teman bermain diluar sekolah yang lebih banyak dari pada anak dari orang tua yang kurang aktif dalam mengatur kontak ini. ${ }^{11} \mathrm{Hal}$ ini menunjukan bahwa anak-anak yang mendapatkan pendidikan sosial yang baik dari keluarga, akan mudah menyesuaikan diri dalam pergaulannya. Anak akan mengetahui batasan-batasan dalam berhubungan sosial dengan teman sebaya, orang yang lebih muda atau orang yang lebih tua. Sehingga anak akan lebih disenangi dalam pergaulannya. Berbagai macam cara dilakukan oleh keluarga dalam memberikan pendidikan terbaik terhadap anaknya. Salah satu yang menjadi perhatian adalah bagaimana pengasuhan yang dilakukan keluarga di rumah. Pengasuhan keluarga di rumah di yakini akan tertanam dalam diri anak dan akan menjadi ciri pribadi anak. Menurut penelitian Diana Bumrind, Dia menjelaskan ada empat jenis gaya pengasuhan yaitu :

\section{Pengasuhan Otoritarian}

Adalah gaya yang membatasi dan menghukum, dimana orang tua mendesak anak untuk mengikuti arahan mereka dan menghormati pekerjaan dan upaya mereka. Orang tua yang otoriter menerapkan batas dan kendali yang tegas pada anak dan meminimalisir perdebatan verbal. Contohnya orang tua otoriter mungkin berkata, "Lakukan dengan caraku atau tak usah.”Orang tua otoriter juga sering memukul anak, memaksakan aturan secara akaku tanpa menjelaskannya, dan menunjukan amarah pada anak. Anak darai orang tua otoriter seringkali tidak bahagia, ketakutan, minder ketika membandingkan diri dengan orang lain, tidak mampu memulia aktivitas, dan memiliki kemampuan komunikasi yang lemah . Putra dan putri dari orrang tua yang otoriter mungkin berperilaku agresif.

2. Pengasuhan Otoritatif

Adalah mendorong anak untuk mandiri namun masih menerapakan batas dan kendali pada tindakan mereka. Tindakan verbal memberi dan

9 Jhon W sanstrock, Perkembangan Anak, Edisi Kesebelas. Jilid 1 (Jakarta: erlangga,2007), 7

\footnotetext{
${ }^{10}$ Op.Cit. 164
}

${ }^{11}$ Ibid, 164 
menerima dimungkinkan, dan orang tua bersikap hangat dan penyayang terhadap anak. Orang tua yang otoritatif merangkul anak dengan mesra dan berkata, Kamu tahu kamu tak seharusnya melakukan hal itu. Mari kita bicarakan bagaiamna kamu bisa menangani situasi tersebut lebih baik lain kali." Orang tua yang otoritatif menunjukan kesenangan dan dukungan sebagai respon terhadap perilaku konstruktif anak. Mereka juga mengharapkan perilaku anak yang dewasa, mandiri dan sesuai dengan usianya. Anak yang memiliki orang tua yang otoritatif seringkali ceria, bisa mengendalikan diri dan mandiri dan berorientasi pada prestasi. Mereka cenderung mempertahankan hubungan yang ramah dengan teman sebaya, bekerjasama dengan orang dewasa dan bisa mengatasi stress dengan baik.

3. Pengasuhan yang mengabaikan

Adalah gaya dimana orang tua sangat tidak terlibat dengan kehidupan anak. Anak yang memiliki orang tua yang mengabaikan merasa bahwa aspek lain kehidupan orang tua lebih penting dari pada diri mereka. Anakanak ini cenderung tidak memiliki kemampuan social. Banyak diantaranya memiliki pengendalian yang buruk dan tidak mandiri. Mereka seringkali memiliki harga diri yang rendah, tidak dewasa, dan mungkin terasing dari keluarga . Dalam masa remaja, mereka mungkin menunjukan sikap suka membolos dan nakal.

4. Pengasuhan Yang menuruti

Adalah gaya pengasuhan dimana orang tua sangat terlibat dengan anak, namun tidak terlalu menuntut atau mengontrol mereka. Orang tua macam ini membiarkan anak melakukan apa yang ia inginkan. Hasilnya, anak tidak pernah belajar mengendalikan perilakunya sendiri dan selalu berharap mendapat keinginannya . Beberapa orang tua sengaja membesarkan anak mereka dengan cara ini karena mereka percaya bahwa kombinasi antara keterlibatan yang hangat dan sedikit batasan akan menghasilkan anak yang kreatif dan percaya diri . Namun anak yang memiliki orang tua yang selalu menurutinya jarang belajar menghormati orang lain dan mengalami kesulitan untuk mengendalikan perilakunya. Mereka mungkin mendominasi, Egosentris, tidak menuruti aturan dan kesulitan dalam hubungan teman sebaya. ${ }^{12}$

Dari empat gaya pengasuhan yang diuraikan oleh Diana Bumrind, yang paling efektif untuk diterapkan adalah gaya pengasuhan otoritatif yang mana keluarga mendorong anak untuk madiri namun tetap memberi batasan akan hal - hal yang bisa dilakukan oleh anak dan yang tidak boleh dilakukan oleh anak. Keluarga senantiasa menjalin komunikasi yang hangat dan mampu menjelaskan sebap akibat dari sebuah tindakan.

Penanaman Nilai-nilai Kehidupan Dalam Keluarga

\footnotetext{
${ }^{12}$ Ibid.
} 
Keluarga adalah lingkungan pertama anak tumbuh dan dibesarkan. Dalam lingkungan keluarga anak mengenal kehidupan sosial yang pertama. Anak akan mengenal nilai- nilai kehidupan dari pengajaran yang diperoleh dalam lingkungan keluarga. Anak yang hidup dalam lingkungan keluarga yang mengajarkan nilai moral yang baik maka anakpun akan memiliki kepribadian yang baik. Begitupun sebaliknya, apabila anak hidup dan dibesarkan dalam lingkungan keluarga yang bermasalah maka akan membentuk pribadi anak yang buruk. Oleh karena itu penanaman nilai-nilai keluarga sangat penting menjadi perhatian orang tua guna untuk membentuk pribadi anak sesuai dengan harapan orang tua. Pribadi anak yang baik akan menjadi bekal dan kontrol bagi diri anak ketika anak berada diluar rumah. Adapun nilai-nilai kehidupan dalam artikel Dunia pendidikan yaitu :

\section{Nilai-Nilai Sosial}

Nilai sosial meliputi rasa hormat, kesopanan, kerja sukarela, kebaikan untuk orang lain, membimbing/menuntun orang lain, sikap disiplin, dan memilih bahasa. ${ }^{13}$ Nilai sosial akan lebih lebih banyak diperoleh oleh anak dalam lingkungan keluarga, hal ini berkaitan dengan bagaimana seorang anak memiliki sikap hormat terhadap orang yang lebih dewasa atau lebih tua, memiliki rasa mengayomi dengan yang lebih muda. Bersikap sopan santun yaitu memiliki perilaku yang baik atau bertindak dengan cara yang dapat diterima secara sosial. Selain itu anak juga dilatih untuk bisa bekerja secara suka rela, misalnya dengan membantu pekerjaan orang tua dirumah sehingga anak diharapkan memiliki sikap peka terhadap lingkungan, mampu berbuat baik kepada orang lain tanpa mengharapkan pamrih. Dengan memberikan tanggung jawab pekerjaan bagi anak maka orang tua secara tidak langsung juga melatih sikap disiplin anak. Komunikasi yang terjalin dalam lingkungan keluarga akan memberi anak pengajaran tentang memilih atau menggunakan bahasa yang baik dalam komunikasi. Itulah sebapnya orang tua perlu mengetahui bahasa dan cara berkomunikasi yang baik dengan anak. Hal ini sejalan dengan yang dikemukakan oleh Tin Herawati bahwa ada tujuh fungsi nilai dasar yang harus ditanamkan dan diterapkan dalam lingkungan keluarga:

a. Toleransi dan saling menghargai, yaitu sikap menghargai dan menerima pendirian yang berbeda atau bertentangan dengan pendirian kita sendiri serta sikaptoleransi dan menerima keberadaan orang lain.

b. Sopan santun, yaitu perilaku yang sesuai dengan normanorma sosial budaya setempat. Sopan santun dipelajari anak melalui teladan atau contoh dari orangtuanya.

\footnotetext{
${ }^{13}$ Dunia Pendidikan, Nilai keluarga. https://duniapendidikan.co.id/.20 Desember 2021.pukul 12.00 WITA
} 
c. Gotong royong, yaitu melakukan pekerjaan secara bersamasama yang dilandasi oleh sukarela dan kekeluargaan. Menumbuhkan jiwa gotong royong dalam kehidupan keluarga berkaitan dengan perilaku anakanak untuk saling menolong dan tanpa pamrih dalam melakukan pekerjaan.

d. Kerukunan dan kebersamaan, yaitu hidup berdampingan dalam keberagaman secara damai dan harmonis. Keluarga sebagai tempat pertama mengajarkan anak dalam kebersamaan dan kerukunan dengan anggota keluarga lainnya.

e. Peduli, yaitu mendalami perasaan dan pengalaman orang lain, serta mempunyai sikap kepedulian terhadap masalah sosial, budaya dan adat yang berbeda yang ditumbuhkan dalam kehidupan keluarga akan membangkitkan rasa kekeluargaan dan kesetiakawanan, menghargai dan menghormati budaya orang lain.

f. Cinta tanah air, yaitu kesadaran diri sebagai bangsa Indonesia yang harus menjunjung tinggi harkat dan martabat bangsa. Cinta tanah air yang ditumbuhkan dalam keluarga akan membangkitkan anak-anak untuk cinta produk dalam negeri dan menghargai perjuangan para pahlawan. $^{14}$

2. Nilai Kewarganegaraan

Meliputi memiliki kesempatan, kebebasan, Patriotisme, Kesetaraan, hak-hak individu, dan menghormati hukum. ${ }^{15}$ Dalam nilai kewarganegaraan dapat diterapkan dengan cara memberi kesempatan kepada anak baik itu dalam hal memberikan pendapat maupun melakukan suatu hal. Anak yang diberi kebebasan atau kesempatan dalam melakukan suatu hal akan memiliki sikap yang patriot. Berani ketika berhadapan dengan hal-hal yang sulit, mampu mengambil resiko, memiliki semangat yang besar serta memiliki rasa percaya diri yang tinggi. Anak juga akan di ajarkan untuk menerima bahwa setiap orang memiliki hak yang sama atas perlakuan yang baik. Selain itu anak juga perlu diajarkan untuk taat terhadap aturan atau hukum, baik itu yang berada dalam lingkungan keluarganya maupun dalam lingkungan masayarakat dan Negara.

3. Nilai Kerja

Meliputi komitmen pada keunggulan, kreativitas dan juga ekspresi, Filosofi belanja, produktivitas, kepuasan dalam pencapaian, kerjasama,

14 Tin Herawati, Penanaman dan Penerapan Nilai Karakter Melalui 8 Fungsi Keluarga. 43

${ }^{15}$ Op.Cit 
keamanan keuangan atau stabilitas, Pendidikan dan pengetahuan. ${ }^{16} \mathrm{Pada}$ nilai kerja anak akan diarahkan untuk mengenal keunggulan dalam diri. Hal ini bisa dilakukan dengan mengamati kegiatan anak, melakukan komunikasi seputar hal- hal apa yang disenangi dan tidak disenangi dilakukan oleh anak. Memberikan kebebasan kepada anak dalam berekspresi dan belajar hal -hal baru. Anak yang memiliki nilai kerja akan memiliki sikap :

a. Percaya diri, yaitu kebebasan berbuat secara mandiri dengan mempertimbangkan dan memutuskan sendiri tanpa bergantung pada orang lain. Anak yang percaya diri ditandai dengan tidak merasa rendah diri dan berani mengungkapkan kemampuannya.

b. Luwes, yaitu mudah menyesuaikan diri dengan situasi dan kondisi dimanapun berada. Anak yang luwes biasanya mudah menerima pendapat orang lain dan mudah bergaul.

c. Bangga, yaitu perasaan senang yang dimiliki ketika selesai melaksanakan tugas atau pekerjaan yang menantang kemudian berhasil meraih sesuatu yang diinginkan. Bangga ditandai oleh kesenangan seseorang setelah berhasil mencapai sesuatu yang diinginkan tanpa diiringi dengan sikap sombong.

d. Rajin, yaitu menyediakan waktu dan tenaga untuk menyelesaikan tugas dan pekerjaannya dan berusaha mendapatkan hasil yang terbaik.

e. Kreatif, yaitu mendapatkan dan mengembangkan banyak cara atau ide untuk melakukan sesuatu hingga berhasil.

f. Tanggung jawab, yaitu mengetahui dan melaksanakan apa yang menjadi tugasnya.

g. Kerjasama, yaitu melakukan suatu pekerjaan secara bersamasama dan ikhlas. ${ }^{17}$

4. Nilai-nilai Agama

Penghormatan kepada Tuhan, Kepatuhan pada perintah-perintah, gaun serta penampilan. Nilai Agama menjadi nilai utama yang didapatkan dalam lingkungan keluarga. Nilai ini akan mengatur bagaimana seorang anak menjalankan perintah TuhanNya dan menjauhi segala laranganNya. Selain itu juga akan mengatur bagaimana tatabusana yang di anjurkan dalam agama. Ada 12 nilai dasar yang harus ditanamkan dalam lingkungan keluarga, yaitu :

a. Iman, yaitu mempercayai adanya Allah SWT, Tuhan Yang Maha Esa dan mengamalkan ajarannya. Taqwa, yaitu mengamalkan segala sesuatu yang diperintahkan dan menghindari segala yang dilarang Allah SWT. 
Moderasi Jurnal Studi Ilmu Pengetahuan Sosial, Volume 2, No. 2, h. 29-4I

b. Kejujuran, yaitu menyampaikan apa adanya.

c. Tenggang rasa, yaitu adanya kesadaran bahwa setiap orang berbeda dalam sifat dan karakternya.

d. Kasih sayang, yaitu ungkapan perasaan dengan penuh perhatian, kesadaran dan kecintaan terhadap seseorang

e. Rajin, yaitu menyediakan waktu dan tenaga untukmenyelesaikan tugasnya dengan berusaha untuk mendapatkan hasil yang terbaik.

f. Kesalehan, yaitu memiliki nilai moral yang tinggi dengan melakukan sesuatu yang benar secara konsisten.

g. Ketaatan, yaitu melaksanakan tugas dan tanggung jawabnya dengan segera dan senang hati.

h. Suka membantu, yaitu memiliki kebiasaan menolong dan membantu orang lain tanpa mengharapkan imbalan.

i. Disiplin, yaitu menepati waktu dan mematuhi aturan yang telah disepakati.

j. Sopan santun, yaitu berperilaku sesuai dengan norma-norma dan nilai-nilai agama.

k. Sabar dan Ikhlas, yaitu kemampuan untuk menahan diri dalam menginginkan sesuatu serta dalam menghadapi kesulitan

1. Kasih sayang, yaitu ungkapan perasaan dengan penuh perhatian, kesadaran dan kecintaan terhadap seseorang.

5. Nilai-Nilai Umum

Meliputi kejujuran, rasa syukur, sikap positif, keberanian,Integritas, kepercayaan, belas Asih, kesabaran, ketekunan, waktu bersama yang berkualitas. ${ }^{18}$ Penanaman nilai-nilai umum dalam lingkungan keluarga sangat penting guna untuk membentuk pribadi anak yang memiliki sikap positif, mampu berkata jujur, memiliki rasa syukur, sabar, tekun, mampu memahami penderitaan orang lain, mempunyai keberanian untuk mengambil sikap,dan dapat memanfaatkan waktu dengan baik.

Nilai-nilai kehidupan akan tertanam dengan baik dalam diri anak apabila orang tua mempunyai komitmen untuk terlibat langsung dalam melakukan pembinaan di dalam rumah. Banyaknya waktu berkumpul dengan keluarga adalah waktu yang tepat dalam menanamkan nilai-nilai kehidupan dalam lingkungan keluarga. Sebagaimana menurut Efendi 1998 peran

\footnotetext{
${ }^{18}$ Loc. Cit
} 
Moderasi Jurnal Studi Ilmu Pengetahuan Sosial, Volume 2, No. 2, h. 29-4I

keluarga adalah memberikan perhatian diantara anggota keluarga, memberikan pendewasaan kepribadian anggota keluarga dan memberikan identitas keluarga. ${ }^{19}$ Menurut Suharno (2012) dalam Tin Herawati,menyatakan bahwa keluarga dalam hal ini orangtua berperan penting dalam membentuk karakter anak karena orangtua merupakan penangungjawab utama dan pertama dalam menanamkan nilai-nilai yang paling mendasar sebelum anak masuk pada fase perkembangan dan pertumbuhan serta lingkungan berikutnya. ${ }^{20}$

Jadi keluarga dalam hal ini mempunyai peran yang sangat besar dalam menanamkan nilai-nilai kehidupan bagi seorang anak. Richardson dan Glesson (2012) dalam Tin Herawati juga menyatakan bahwa perbaikan peran keluarga berpengaruh positif terhadap kualitas dan kesejahteraan anak. Kondisi tersebut disebabkan karena peran keluarga mempengaruhi gaya pengasuhan orang tua terhadap anak. Pelaksanaan peran keluarga yang optimal dapat memberikan peluang kepada keluarga untuk melahirkan generasi penerus berkualitas sehingga diharapkan akan menjadi pemimpin bangsa yang berkualitas. ${ }^{21}$

\section{Kesimpulan}

Salah satu kebijakan yang dibuat oleh pemerintah guna untuk meminimalisir penyebaran virus Covid-19 yaitu Work From Home (WFH). Hal ini sebenarnya perlu disambut baik oleh keluarga, dengan adanya kebijakan WFH keluarga memiliki banyak kesempatan untuk mendampingi anak secara langsung ketika belajar sehingga dapat mengetahui sejauh mana tingkat kemampuan perkembangan anak dalam belajar dan menjadi kesempatan bagi keluarga untuk menjalin kedekatan emosional yang lebih kuat antara orang tua dan anak. Sehingga akan lebih mudah bagi keluarga menjalankan perannya dalam menanamkan nilai-nilai kehidupan bagi Anak.

Dalam kehidupan pertamanya anak akan tumbuh dan berkembang dalam lingkungan Keluarga. Lingkungan dimana anak akan mendapatkan pengajaran pertama dalam hidupnya. Ada empat gaya pengasuhan yang perlu diketahui oleh keluarga yaitu pengasuhan otoritarian, pengasuhan otoritatif, pengasuhan yang mengabaikan dan pengasuhan yang menuruti. Dari empat gaya pengasuhan yang diuraikan oleh Diana Bumrind, yang paling efektif untuk diterapkan adalah gaya pengasuhan otoritatif yang mana keluarga mendorong anak untuk madiri namun tetap memberi batasan akan akan hal - hal yang bisa dilakukan oleh anak dan yang tidak boleh dilakukan oleh anak. Keluarga senantiasa menjalin komunikasi yang hangat dan mampu menjelaskan sebap akibat dari sebuah tindakan.

\footnotetext{
19 ibid,

${ }^{21}$ Ibid.,Hal. 18

${ }^{20}$ Op.Cit. 20
} 
Moderasi Jurnal Studi Ilmu Pengetahuan Sosial, Volume 2, No. 2, h. 29-4I

Keluarga adalah lingkungan pertama anak tumbuh dan dibesarkan. Dalam lingkungan keluarga anak mengenal kehidupan sosial yang pertama. Anak akan mengenal nilai- nilai kehidupan dari pengajaran yang diperoleh dalam lingkungan keluarga. Adapun nilai-nilai kehidupan yang perlu di tanamkan dalam diri anak yaitu nilai-nilai sosial, nilai kewarganegaraan, nilai kerja, nilai agama, dan nilai-nilai umum. Jadi keluarga dalam hal ini mempunyai peran yang sangat besar dalam menanamkan nilai-nilai kehidupan bagi seorang anak. Richardson dan Glesson (2012) dalam Tin Herawati juga menyatakan bahwa perbaikan peran keluarga berpengaruh positif terhadap kualitas dan kesejahteraan anak. Kondisi tersebut disebabkan karena peran keluarga mempengaruhi gaya pengasuhan orang tua terhadap anak. Pelaksanaan peran keluarga yang optimal dapat memberikan peluang kepada keluarga untuk melahirkan generasi penerus berkualitas sehingga diharapkan akan menjadi pemimpin bangsa yang berkualitas.

\section{Referensi}

Data Vaksin Covid 19.https://covid19.go.id/p/berita/data-vaksinasi-covid-19-update-26desember-2021. Di akses 26 Desember 2021

Dunia Pendidikan, Nilai keluarga. https://duniapendidikan.co.id/.20 Desember 2021.pukul 12.00 WITA

Ekon.gi.id. https://ekon.go.id/publikasi/detail/3159/penerapan-ppkm-untuk-mengendalikanlaju-covid-19-dan-menjaga-kehidupan-masyarakat. Di akses 20 Desember 2021

Herawati Tin, Penanaman dan Penerapan Nilai Karakter Melalui 8 Fungsi Keluarga. Jakarta: Erlangga. 2017

http://ejurnalmalahayati.ac.id/index.php/medika/article/view/3174/pdf. Diakses pada 18 Desember 2021

Jhon W Santrock. Perkembangan Anak. Edisi ke sebelas Jilid 1, Erlangga : PT Belora Aksara Pratama. 2007.

Jhon W Santrock. Perkembangan Anak. Edisi ke sebelas Jilid 2, Erlangga : PT Belora

Aksara Pratama. 2007.

Paules CI, Marston HD, Fauci AS. Coronavirus Infections-More Than Just the Common Cold. JAMA.2020;323(8):707-708. doi: 10.1001/jama.2020.0757

Rothan HA, Byrareddy SN. The epidemiology and pathogenesis of coronavirus disease (COVID-19) outbreak. J Autoimmun. 2020; published online March 3. DOI: $10.1016 /$ j.jaut.2020.102433.

Singgih D. Gunarsa, Psikologi Untuk Keluarga Jakarta: PT. BPK Gunung Mulia, 2011. 
Moderasi Jurnal Studi Ilmu Pengetahuan Sosial, Volume 2, No. 2, h. 29-4I

Tentang Covid 19.https://covid19.go.id/tentang-vaksin-covid19. Di akses 20

Desember 2021

World Health Organization. Naming the coronavirus disease (COVID-19) and the virus that causes it [Internet]. Geneva: World Health Organization; 2020 [cited 2020 March 29]. Available from: bttps:// www.who.int/emergencies/diseases/novelcoronavirus-2019/technicalguidance/ naming-the-coronavirusdisease-(covid-2019)-and-the-virus-that-causes-it. Diakses pada 01 Desember 2020

World Health Organization. Situation Report - 42 [Internet]. 2020 [updated 2020 March 02; cited 2020 March 15]. Available from: https://www.who.int/docs/default-source/ coronaviruse/situationreports/20200302-sitrep-42-covid-19. pdf?sfvrsn=224c1add_2.

World Health Organization. WHO Director-General's opening remarks at the media briefing on COVID-19 - 11 March 2020 [Internet]. 2020 [updated 2020 March 11]. Available from: bttps://wmw.who.int/dg/speeches/detail/whodirector-generals-opening-remarks-at-the-media-briefing-on-covid-19---11- march-2020. Diakses pada 19 Desember 2021 